\title{
Project Financial Management
}

Projects are the basic units and cells of business management at Huawei. There are different types of projects, including $\mathrm{R} \& \mathrm{D}$, sales, delivery, and management transformation projects. If projects are not effectively managed, it will be impossible for a company to achieve robust operations. Huawei is working hard to shift its operating model from being functioncentered to being project-centered. This is going to be a huge change. It means thousands of field teams will be mobilized. It also means that functional departments will no longer be centers of authority, but centers of expertise and resources. Huawei believes that a project-centered model will help reduce redundancy and avoid the pitfalls experienced by large companies that operate with a function-centered organizational structure. The project-centered model will also make the company more competitive and enable managers to develop rapidly.

To adopt a project-centered model, a company needs to establish a corporate-level project management system. Moving forward, Huawei aims to build a management system like a dragon, whose head moves flexibly to look for food or attack a target. Its bone systems are flexible and powerful to ensure that the whole body moves to support any attack the head may start. Our field project operations must be as flexible as a dragon's head and our back-office management support systems must be like a dragon's bone systems. This will make up the basic architecture of our future management system. 
When it comes to project financial management, we first need to improve the closed-loop management of project estimation, budgeting, accounting, and final accounting. For projects that can be measured by profits and losses, we should run them as profit centers, and establish project operations management, appraisal, and Contribute and Share systems based on revenue, profits, and cash flow. For delivery projects that are run as cost centers based on budget targets, we need to integrate pre-sales and post-sales activities, align accounting with budgeting and final accounting with estimation, and perform closed-loop management of assumptions and risks. We also need to establish an incentivization system based on the completion of budget targets to inspire passion across project teams.

This chapter discusses how Huawei manages project finances. Although financial management is only a sub-system of the project management system, it penetrates deep into all kinds of business activities and runs through the entire lifecycle of a project.

\subsection{Shifting from Being Function-Centered to Being Project-Centered}

\subsubsection{Projects Are the Basic Units and Cells of Business Management}

Huawei is gradually changing its corporate governance model from one that is centralized to one that enables field teams to call for support. Under this new model, field teams will have both responsibility and authority while back offices provide enablement training and take responsibility for oversight. Such a model is built on an effective management platform with elements such as processes, data, information, and authority. Over the past 20 -plus years, with the help of Western consultants, we have established a relatively unified platform that provides guidance and support to field offices. In the next five to ten years, we will gradually delegate decisionmaking authority to the field and provide the right level of support to help them exercise authority. (Ren Zhengfei: Applying the Spirit of the Tortoise to Catch up with the Dragon Spacecraft-Speech at Huawei Annual Management Conference 2013, Huawei Executive Office Speech No. [2013] 255)

Only by being project-centered can we avoid the pitfalls experienced by large companies that operate with a function-centered organizational structure. The project-centered model can also make our company more 
competitive. We need to quickly change our operating model from being function-centered to being project-centered. Projects are the basic units and cells of business management. If projects are not effectively managed, it will be impossible for the company to achieve robust operations. Over the next two to three years, we will change the way we operate, from being function-centered to being project-centered. This is going to be a huge change. It means thousands of field teams will be mobilized. It also means that functional departments will no longer be centers of authority, but centers of expertise and resources. In 2014, we will further delegate budgeting, accounting, and incentivization authority to project teams, so that this most basic unit of business operations can be mobilized. (Xu Zhijun: Focusing on Strategy, Streamlining Management, and Achieving Sustainable and Profitable Growth, Huawei Executive Office Speech No. [2013] 246)

Project management is the basic cell that promotes improvements to company management. We must continue to improve project management as the most important type of management at Huawei. Project management training offered by Huawei University should be systematic. Projects are basic units of operations so we must continuously improve our project management. People who truly understand project management have the potential to be top leaders. Managers who fail to manage projects effectively won't be able to manage representative offices and regions effectively. (Ren Zhengfei: Speech at a Work Report by the Huawei University Institute of Education, Huawei Executive Office Speech No. [2013] 242)

Huawei's management improvement has to be built on project management improvement. People in the eight critical project roles ${ }^{1}$ should be carefully selected and developed. Mature procedures and a large highcaliber management team have to be developed. We should build a pool of managers and experts on project management through the Strategic Reserve. We need to pass advanced methods and capabilities on to representative offices through employee rotation. We should be good at identifying "golden seeds" (people with high potential) and allocate them to different places to sprout and bloom. These transformations represent opportunities for departments at all levels to create value; they are also the

${ }^{1}$ The eight critical roles of a project include Project Manager (PM)/Project Control Manager (PCM), Technical Director (TD)/Technical Leader (TL), Project Financial Controller (PFC), Delivery Quality Assurance Engineer (DQA), Supply Chain Manager (SCM), Procurement Project Manager (PPM), Contract Manager (CM), and Project HR. 
test beds that we can use to identify and develop managers. (Ren Zhengfei: Applying the Spirit of the Tortoise to Catch up with the Dragon SpacecraftSpeech at Huawei Annual Management Conference 2013, Huawei Executive Office Speech No. [2013] 255)

\subsubsection{Establishing a Corporate-Level Project-Centered Management System}

I think our future management system should consist of front, middle, and back ends. The front end is a project operations or action center that has clear targets. The middle end is an efficient platform from which the front end can call for support. It serves as a bridge between the front and back ends and streamlines both information and goods. It is an integrated service platform that consists of "satellites", "aircraft carriers", and communications systems. The back end is a decision-making and oversight center that has a clear view of front-end activities. This center is there to make sure that all front-end activities are transparent and comply with related business rules. (Ren Zhengfei: Rigorous, Well-ordered, and Simple Management Is Crucial for Huawei to Scale New Heights, Huawei Executive Office Speech No. [2014] 028)

A corporate-level project management system is needed to adopt a company-wide project-centered model. Moving forward, Huawei aims to build a management system like a dragon, whose head moves flexibly to look for food or attack a target. Its highly developed bone systems are well-coordinated to ensure that the whole body moves to support any attack the head may start. In the field, our project operations must be as flexible as a dragon's head and our back-office management support systems must be like a dragon's bone systems. This will make up the basic architecture of our future management system. (Guo Ping: Becoming Project-centered to Support the Company's Sustainable and Profitable Growth-Speech at the 2014 Project Management Summit, 2014)

Huawei is changing its operating model from one that is functioncentered to one that is project-centered. In the future, customer, $R \& D$, service, and transformation projects will be the primary building blocks of the company's operations. We will face numerous management problems. We need to ask ourselves many questions: How should we establish a three-level management system for project portfolios, programs, and projects? How should we streamline operations from end to end and make project operations a true reality by getting GTS and supply chain staff 
involved earlier in projects? How should we position various projects as responsibility centers and delegate authority appropriately based on their positioning? How should back-end support platforms respond to the call for resources by projects? How can we ensure effective resource allocation by combining our pull and push strategies with HQ being pulled by field offices? We need to delve deeper into these questions and explore ways to resolve them. The company's shift to a project-centered model will help reduce redundancy and avoid the pitfalls experienced by large companies that operate with a function-centered organizational structure. Such a model will also hone our competitive edge and enable managers to develop rapidly. (Ren Zhengfei: Speech at the Awards Ceremony for Whiz Kids, Huawei Executive Office Speech No. [2014] 039)

In the future, Huawei's model of operations should be integrated. This is known as the "Squad Leaders' Fight". After authority is delegated to field offices, we will make field operating teams leaner, downsize back offices, and step up efforts to build strategic mobile teams. The purpose of having smaller operating teams is not to further fine-tune the division of responsibilities. Instead, we are looking to significantly enhance their operating capabilities by equipping them with advanced tools and providing them with strong support. Of course, it is impossible to delegate authority overnight. Currently, there are still many management problems. Over the next three to five years, we will focus on streamlining LTC and achieving CIAG and Five Ones. Five years from now, we will resolutely allow field teams to gradually call for support, and resolutely remove redundant organizations at $\mathrm{HQ}$. This way, our $\mathrm{HQ}$ will become less bureaucratic. (Ren Zhengfei: Speech at the Briefing on HR Work, Huawei Executive Office Speech No. [2014] 057)

Being project-centered is not just about running front-end business by projects. It also needs a management support system to provide full support for projects. In other words, we need to create a complete architecture to streamline both the front and back ends, involving people, processes, knowledge, strategies, and many other aspects. This is what the industry calls a corporate-level project management system. (Guo Ping: Becoming Project-centered to Support the Company's Sustainable and Profitable Growth-Speech at the 2014 Project Management Summit, 2014)

We will stay customer-centric and gradually change our centralized resource allocation model. In the future, our resource allocation will be aligned with strategy, enabling those in field offices to call for support. Under this new resource allocation model, field teams will have both 
responsibility and authority while back offices provide enablement training and take responsibility for oversight. This model will combine the "pull" and "push" strategies, with the "pull" strategy playing the leading role. Field operating units make every endeavor to seize opportunities for sustainable and profitable growth. The big platform at back offices not only needs to meet the support demand of field offices; but also needs to focus on our core business, and allocate strategic resources to create more demand and opportunities for our core business. This is the architecture of our future-oriented management system, and also an important means to ensure that we are able to scale new heights. (Guo Ping: Transform Continuously and Improve Field Operating Capabilities to Ensure the Company's Sustainable and Profitable Growth-Speech at Huawei Annual Management Conference 2013, Huawei Executive Office Speech No. [2014] 020)

Right now, our project management capabilities are still weak and there is still much waste. We need to equip our project teams with improved skills. Why was HQ so strong before? Because HQ controlled budgets: It approved its own bonuses, staffing, and job grades first. It would then send out employees with personal grades of 14 or 15 to field operating teams. Their personal grades were low and they still needed to figure out how to do their jobs. By the time they worked things out, large amounts of effort, time, and materials had already been wasted. Why couldn't we cultivate several generals with the money wasted? This was the problem with our function-centered model. In the future, we will adopt a projectcentered model. We are already piloting it now. Going forward, we will gradually give more authority to our field operating teams and will also move oversight forward to the field to ensure better delegation and exercise of authority. Radical transformation, however, could be catastrophic to the organization. It takes time to transform a company's platform. We need to be patient and make concerted efforts to make it happen. During the process, a large number of outstanding managers will emerge. (Ren Zhengfei: Heroes Are All Around Us-Speech at the Q4 Regional Presidents' Meeting, Huawei Executive Office Speech No. [2014] 086)

The ultimate goal of our transformation is to change from being function-centered to being project-centered. Under the project-centered model, project managers will have planning, budgeting, and crosscharging authority, and will have control over project budgets. They can purchase resources based on project needs. Processes, departments, people, and actions that don't create value for customers are redundant. 
When we remove such redundancy, Huawei's HQ will become less bloated. (Ren Zhengfei: Generals Are Born of Battle-Speech at the 2015 Project Management Summit, Huawei Executive Office Speech No. [2015] 118)

\subsubsection{Back Offices Need to Collaborate to Provide Timely and Accurate Support for Field Operations}

In the future, our organizational structure will look like a spindle - HQ departments are at the top; regions, product lines, and other execution departments in the middle; and representative offices and production lines at the bottom. Departments at HQ will be small in number and scale and will be composed of people with successful field experience. They understand the needs of field offices, have clear strategies and tactics, make correct decisions, respond quickly, and provide excellent services. Since functions will be integrated, the number of HQ departments will be reduced. The middle segment is responsible for numerous operating tasks. Since a lot of specific and specialized support needs to be provided, the middle segment has detailed division of responsibilities and a larger number of departments. Departments at the bottom are responsible for operations and execution. Functions of those departments need to be integrated, and don't need to be aligned with those of departments in the middle. Otherwise, there will be too much coordination and internal friction, which will lead to bureaucracy in field offices. That is why we have a smaller number of departments at the bottom. (Ren Zhengfei: Speech at the UK Representative Office, Huawei Executive Office Speech No. [2007] 027)

We have made it clear that our transformation should center on the actual needs of field offices. Back offices (including field teams that are not directly involved in project operations) should promptly and accurately address the needs of field operating teams. We establish departments to fight battles and we fight battles to make profits. Back offices should be established based on the needs of field teams, and must focus on supporting field teams. We should also further integrate business functions in back offices to reduce the number of functional departments and internal coordination, and thus provide timely and accurate services to field teams. (Ren Zhengfei: Who Calls for Artillery and How Do We Provide Timely Artillery Support? - Speech at the Awards Ceremony of Sales o Services, Huawei Executive Office Speech No. [2009] 001) 
Field offices must provide accurate information about their needs, and back offices must accurately understand the needs and provide support as needed. (Ren Zhengfei: Who Calls for Artillery and How Do We Provide Timely Artillery Support?-Speech at the Awards Ceremony of Sales \& Services, Huawei Executive Office Speech No. [2009] 001)

Back offices will become a systematic support force and must provide timely and effective support and services. They also need to be responsible for analysis and oversight. As a back-end organization, HQ does not represent the company. It must provide support and services to field offices and avoid being bossy and arrogant. (Ren Zhengfei: Who Calls for Artillery and How Do We Provide Timely Artillery Support?-Speech at the Awards Ceremony of Sales \& Services, Huawei Executive Office Speech No. [2009] 001)

We are now engaged in too much internal coordination. I think we should have fewer teams in back offices; their functions can be integrated to reduce coordination. They need to coordinate efforts to provide integrated services. You need to take time to figure out what this means. Back offices must deal with difficulties themselves and should not bother field offices with this. For example, field offices make numerous calls to resolve conflicts between two managers from back offices. Why don't back offices integrate their functions into a unified administrative organization and deal with all difficulties internally? As company operations become more standardized and organized, we need to integrate business department functions as appropriate and reduce headcount, giving more responsibilities to employees in similar roles. This may help us work more efficiently. (Ren Zhengfei: Speech at the EMT ST Meeting, April 2010)

\subsection{Key Activities for Project Financial Management}

\subsubsection{Closed Loop Operations: Project Estimation, Budgeting, Accounting, and Final Accounting}

\section{Perform accounting by project and customer}

Projects and customers are basic units in business management. Representative offices should focus on projects and customers, and perform accounting by project and customer. Like a cell in an organism, a project is the most important building block of an organization. Without project accounting, it won't be possible for account departments and 
representative offices to effectively manage their business operations. Once we are clear about projects and customers, we will have a clear picture of our account departments. This will help us better measure what our representative offices and regions have done in the past. (Ren Zhengfei: Integrating Project Estimation, Budgeting, Accounting, and Final Accounting to Support Project Operations-Speech at a Briefing on the IFS Project, Huawei Executive Office Speech No. [2010] 007)

Project cost accounting is the basis for effective management in departments at all levels. (Ren Zhengfei: Staying Customer-centric, Inspiring Dedication, and Persevering Are Key to Our Success-Speech at the 2010 Huawei Market Conference, Huawei Executive Office Speech No. [2010] 002)

The company is now focused on developing profit-centric organizations. HQ must provide services to profit centers. In the future, profit centers will view project profits as a key factor in their decisions. Project managers must be project-centric and ensure profits. (Ren Zhengfei: Remarks at a Meeting with Senior Managers at a Project Management Summit, Huawei Executive Office Speech No. [2009] 007)

Project estimation, budgeting, accounting, and final accounting are key activities in project operations management. Project estimation is the process of planning project profits; budgeting and accounting involve managing revenue increases and cost savings; and final accounting is the process of passing on the experience and lessons learned in a project. The purpose of integrating these four activities is to serve account departments and project teams, and support business management at the project level. (Ren Zhengfei: Integrating Project Estimation, Budgeting, Accounting, and Final Accounting to Support Project Operations-Speech at a Briefing on the IFS Project, Huawei Executive Office Speech No. [2010] 007)

If we are not clear about planning, budgeting, and accounting, and what surrounds these three mechanisms, then our transformation will ultimately remain function-centered. That means we would still allocate resources and perform accounting based on functional departments. It would be impossible to streamline our management. We haven't touched upon the major issues during our transformation. (Ren Zhengfei: Rigorous, Well-ordered, and Simple Management Is Crucial for Huawei to Scale New Heights, Huawei Executive Office Speech No. [2014] 028)

When it comes to project operations, we first need to improve our budgeting and accounting capabilities. Project budgets must be reliable, clear, and executable. Project accounting must be accurate, complete, and 
measurable. We need to identify those who perform well in project budgeting and accounting and make fast-track promotion available to these employees. This can motivate employees and inspire passion across the entire organization. (Ren Zhengfei Minutes of the Meeting on the Budgeting Work, Huawei Executive Office Speech No. [2014] 004)

A project will become a command center once it has a budget. Our total budget system needs to provide support for this kind of operating mechanism. We must pay special attention to the cost of resources used in a project, and make all resources and their costs transparent. This will enable project teams to select the resources they need. (Ren Zhengfei: Minutes of a Briefing on the Progress of the Project for Changing Functioncentered Operations into Project-centered Operations, EMT Meeting Minutes No. [2014] 019)

A project-centered budgeting system means that we need to manage planning, budgeting, accounting, and assessment in a closed-loop manner, linking the budgets of responsibility centers to project budgets. When preparing project budgets, we should go beyond sales projects and delivery projects, and also focus on leads and opportunities that are aligned with our customers' investment plans. This can ensure budgets are generated based on projects (Budgets for responsibility centers $=\sum$ Project budgets + Expenses funded by the company). Currently, the quality of our project estimation, budgeting, accounting, and final accounting is not high. About $65 \%$ of projects see a deviation of 15 percentage points in contribution gross profit rates between budgeted amount and actual figures. About $36 \%$ of projects witness a deviation of $15 \%$ between the rolling forecasts and actual figures. The GTS and Sales \& Delivery Finance Management Department must analyze the root causes behind major issues in project estimation, budgeting, accounting, and final accounting, set clear goals for improvement, and make improvements as planned. (Source: Minutes of the Work Report on the Project for Changing Functioncentered Operations into Project-centered Operations, BOD Executive Committee Meeting Minutes No. [2015] 020)

Over the entire project lifecycle, the project budget must be aligned with both our customer's and Huawei's annual budgets. Both we and our customers manage budgets on an annual basis, so the full lifecycle budget of the project must be broken down based on the customer's and Huawei's annual budgets. This supports operations management in representative offices and ensures our budget is reliable. (Source: Minutes of the Meeting of the Finance Committee Office, July 2015) 
Project estimation, budgeting, accounting, and final accounting are key activities in project operations management. The following rules must be followed throughout the lifecycle of a project: Project estimation helps optimize solutions, make informed sales decisions, and set initial project goals. Project budgeting must align with project estimation. Resources are allocated based on project budgets to support the attainment of project goals. Comprehensive assessment of project operations must be based on project final accounting. A resource buy \& sell mechanism needs to be established to improve efficiency. (Source: Project Operations and Management Policy, Corp. Doc. No. [2013] 160)

\section{Project estimation is the basis for contract negotiation}

Project quotations should be supported by cost baselines and should be used as budgets for project delivery throughout the project management process. Project managers should take care of both project delivery and project financial targets. The purpose of sales and delivery is to collect payments. (Ren Zhengfei: Keeping Customer PO Information Transparent to Support Payment Collection, Revenue Recognition, and Project Budgeting and Accounting - Speech at a Work Report by the IFS Project Team, Huawei Executive Office Speech No. [2009] 002)

The reason why we put project estimation and contract negotiation in the same COE is that contract negotiation is based on project estimation. We can't negotiate with customers before getting project estimation straight. We could select some outstanding employees in India and build a global COE for bidding, project estimation, and contract negotiation in order to integrate these activities. (Ren Zhengfei: Keeping Customer PO Information Transparent to Support Payment Collection, Revenue Recognition, and Project Budgeting and Accounting-Speech at a Work Report by the IFS Project Team, Huawei Executive Office Speech No. [2009] 002)

Project estimation must be performed by project operations managers. All managers are estimation managers. They should have a clear idea about estimation. If they do not have accurate profit estimations for this year, how can they make money? At the representative office level, representative office general managers and account department directors are estimation managers. Business financial controllers (BFCs) of account departments do the specific work. (Ren Zhengfei: Integrating Project Estimation, Budgeting, Accounting, and Final Accounting to Support Project Operations-Speech at a Briefing on the IFS Project, Huawei Executive Office Speech No. [2010] 007) 
We do not know that much about estimation. What is the coefficient for the contract under this contract scenario? What is the standard coefficient? How many estimation models do we have? We do not know the answers. Instead, we just make guesses and give approximate numbers. If the CFO gets a number approximately the same as ours through actuarial work, we cannot just leave it alone. We need to analyze why there is a difference. We also need to assign people to check, as this can help us determine what the average number is and which one is more accurate. The purpose here is not to argue about who is right or wrong, but to figure out how to be more accurate. We need to strike a balance in our work. When our schedule is not that busy, we need to plan and check our contract scenarios efficiently and quickly. To thrive, our Latin America Region first needs to make profits. Even in strategic opportunities, we also need to turn a modest profit. The region is facing numerous issues, such as foreign exchange controls. Since you cannot grow your business right now, you should instead focus on seeking more profits. (Ren Zhengfei: Speech at a Briefing of the Northern Latin America Region and Colombia Representative Office, Huawei Executive Office Speech No. [2014] 051)

Resources incur costs - Those who call for resources should bear the costs

Field offices know best about what's going on in the field and can best assess project workload. While ensuring respect for the company's general principles and objectives, we need to allow autonomy in basic operating units, giving them the authority to decide on tactics and operations, staffing, and resource allocation. HR departments are mainly responsible for resource quality, while project managers determine resource allocation. There should be no bureaucratic restrictions or rigid execution. HR departments should not create barriers when project managers ask for resources. Field teams know the field and projects best, so we must give project managers more flexibility in resource allocation. (Source: Remarks by Ren Zhengfei and Sun Yafang at a Briefing on Improving ReD Organization Operations, 2001)

How do we coordinate resources? The key is to make it clear that resources incur costs and profit centers must bear the expenses and costs incurred for their own development. Only in this way can we say: the more opportunities, the better. When we find ourselves short of resources, it means we have too many profitable opportunities. We have people flying to different parts of the world all the time to provide services, and profit centers should bear the expenses incurred for this. What 
does calling for resources mean? It is actually about allocating the expenses incurred to profit centers. But I think there is still a problem. How can we ensure all expenses incurred by services for a project are allocated specifically to that project? We do not have a reasonable formula. This puts us at a disadvantage in terms of human resource management. Chen Yongzheng, a former Microsoft executive, said he did not have money and he couldn't understand why Huawei spent extravagantly. He also said that he needed to ask for money from project teams in representative offices. He would say to project teams, "I have provided you with services, so you have to pay me." At Microsoft, profit centers have the budget. In contrast, Huawei's HQ has a lot of money and has a large number of people, resulting in bloated functional departments. That's the problem with our accounting system. (Ren Zhengfei: Speech at a Meeting with the IFS Project Team and Staff from Finance, Huawei Executive Office Speech No. [2009] 004)

Representative offices need to ensure that their demand for goods is accurate. If goods are returned due to mistakes in your plan, the losses incurred will be deducted from your compensation packages. This is the only way for us to make sure that everyone at representative offices takes the accuracy of their goods demands seriously and prevent overstock. If we have too much overstock, costs and expenses will run out of control. Management savings of the company are directly reflected in our compensation packages. (Ren Zhengfei: Comments to Staff of the Brazil Representative Office and Brazil Supply Center, Huawei Executive Office Speech No. [2014] 050)

We need to gradually reduce how much secondary sorting we do in warehouses. Warehouse expenses and inventory costs must be allocated to beneficiary departments. But how can we truly reduce our secondary sorting? We need to make sure whoever benefits pays. First, all expenses, such as warehouse rent and labor expenses, should be allocated to those who benefit from them. Otherwise, we will still manufacture products blindly. Second, in the future, most expenses incurred during inventory, return, and scrapping, if not all expenses, should also be allocated to beneficiary departments. Third, supply center warehousing costs should also be allocated to beneficiary departments. If money is saved through direct shipment, rather than using supply center warehouses, we can take a portion from the saved money to reward the department involved. (Ren Zhengfei: Doing It Right the First Time-Speech at the Global Warehouse Meeting, Huawei Executive Office Speech No. [2014] 060) 
What is the relationship between the financial budget and the headcount budget for delivery resources? Project teams must make plans and prepare budgets for their headcount. We have set clear rules for budget changes, which can flexibly adapt to business changes as needed. The company has formulated strict regulations on headcount control. Because of this, it is difficult for representative offices and resource pools to increase headcount to meet growing business needs. This is a systematic issue. We need to reveal the issue through this pilot project. We don't yet have a mechanism for adjusting project headcount, nor do we have trust-based headcount forecasting and approval. We need to work hard to resolve these issues. What resources do projects need? How do resource departments provide resources? We need to study our resource demand and supply mechanism and strike a balance in this regard. On one hand, we need to emphasize that project teams must develop accurate project resource plans. On the other hand, we must also make it clear that departments that supply resources must take primary responsibility for managing their entire resource plan and coordinating resources. If a project resource plan needs revision, the project team needs to apply for more resources or release resources in advance. The needed lead time can vary by resource level. If a project team fails to apply for more resources or release resources in advance, departments that supply resources can refer to the quotation approach adopted by the Translation Services Center and refund approach used in procurement. In this way, our project teams and departments that supply resources jointly bear costs. (Source: Minutes of the Meeting of the Finance Committee Office, July 2015)

Managing project profits and losses, cash flow, and working capital efficiency based on baselines

When assessing the value of a project, we need to assess the project's profits and losses, cash flow, and working capital efficiency, and manage them against baselines. We will continue to improve end-to-end transaction quality and manage it as a top priority of the company. During project execution, we need to closely follow the project plan, stay on budget, and effectively manage project costs, profits, and cash flow to ensure delivery quality. (Source: 2010 Key Work Requirements, EMT Resolution No. [2010] 007)

Each country office in the Northern Latin America Region needs to establish its own baseline. You can establish a baseline by analyzing data from the past three years and make improvements against the baseline. For example, you can compare data of this year with that of last year. You 
don't have to seek a unified baseline, as each country is very different. You should not aim for the best, optimal, or most scientific baseline. Instead, you should use a balanced scoreboard. If you find there are no improvements over the previous year in a given area, you should focus on improving this area next year. This can help improve your management over the long term. Under the Contribute and Share system, both improvements and waste are directly linked to your personal interests. In this way, our expense management will become more scientific. (Ren Zhengfei: Speech at a Briefing of the Northern Latin America Region and Colombia Representative Office, Huawei Executive Office Speech No. [2014] 051)

We need to keep optimizing baseline management for representative offices. Each country office should set its own baseline as appropriate. We will explore ways to further optimize baseline management with the help of IT systems and AI technology, which will make this work simpler. Though we do not have clear baselines now, I believe we will develop more scientific baselines. (Ren Zhengfei: Speech at a Briefing on Improvements and Future Planning for Carrier and Enterprise Regional Organization Transformation, Huawei Executive Office Speech No. [2017] 030)

\subsubsection{Building an Awareness of Project Operations and a Project Operations Management Mechanism}

(1) Projects are the basic units and cells of business management at Huawei. If projects are not effectively managed, it will be impossible for the company to achieve robust operations. (2) Project management teams are operating units. C\&Q management should cover managers in both permanent and temporary project teams. We should select managers from amongst outstanding project management teams. (3) The annual budget needs to be prepared based on projects or opportunities. Resource allocation should also be based on projects. Project management teams need to buy resources from supporting departments according to their business plans and granted budgets. Supporting departments need to be responsible for resource efficiency. (4) Project management teams are the basic units that manage company operations. Representative offices, account departments, and product lines comprehensively manage project operations from three dimensions: product, customer, and region. The aim is to ensure balanced business development across the company. (5) Employee responsibilities in terms of project operations management must be clearly 
defined. Only when responsibilities are assigned to individuals and only when managers are appraised based on the results they deliver, can our employees truly assume responsibilities, help streamline management, and ultimately improve efficiency. (Ren Zhengfei: Speech at a Briefing on the IFS-PFM Project, Huawei Executive Office Speech No. [2013] 074)

We need to change our project operations from relying on individual capabilities to relying on organizational capabilities. (Ren Zhengfei: Speech at a Briefing on the IFS-PFM Project, Huawei Executive Office Speech No. [2013] 074)

We attach great importance to field experience, which means experience in project operations management. Projects here include sales, delivery, and R\&D projects. When selecting and deploying managers, we pay special attention to field and project experience. (Ren Zhengfei: Speech at a Briefing on the IFS-PFM Project, Huawei Executive Office Speech No. [2013] 074)

We should always select managers from outstanding project management teams. Project results should be linked to the removal of underperforming managers. We should let the top-performing $30 \%$ of project teams take over the bottom 30\%. This move will help us constantly improve project operations management. Through this mechanism, we have improved the expertise of our managers, especially those at the junior and middle levels. (Ren Zhengfei: Speech at a Briefing on the IFS-PFM Project, Huawei Executive Office Speech No. [2013] 074)

Huawei's project operations are essentially about defining small operating units. Large companies need to be as dynamic and agile as small companies, but can our systems provide strong support in this regard? Large companies are afraid of rigidity, whereas small companies fear losing control. (Ren Zhengfei: Rigorous, Well-ordered, and Simple Management Is Crucial for Huawei to Scale New Heights, Huawei Executive Office Speech No. [2014] 028)

Guo Ping said our growth should no longer be driven by scale, but by efficiency and profits. Project operations management is an important way to get there. It is also a basic skill required of all managers. (Ren Zhengfei: Applying the Spirit of the Tortoise to Catch up with the Dragon SpacecraftSpeech at Huawei Annual Management Conference 2013, Huawei Executive Office Speech No. [2013] 255)

People in the eight critical roles of a project need to share the responsibility for high-quality project operations. The specifics of these responsibilities vary from role to role. In a project-centered operations pilot 
project, the Germany Representative Office can explore multiple approaches and ensure that all critical roles in the project assume common but differentiated responsibilities. For example, the PFC takes special responsibility for the accuracy of project budgets, forecasts, and accounting, and will be disciplined if any financial problems occur. If inaccurate financial data is produced during actual operations, the PFC needs to identify the root cause of the inaccuracy. This is also an opportunity for PFCs to get involved in business and continuously improve their project accounting skills. (Source: Minutes of the Meeting of the Finance Committee Office, July 2015)

Why do our projects fail to generate profits? The real reason is that our project managers do not conduct accounting properly in the first place. When you have too many resources, you get sloppy. Our project managers are focusing on delivering to customers, but they forget that they have another objective - to earn a profit. We stay customer-centric, but we also have to make profits. Our management at the moment is not effective: Project managers don't understand finances, and project CFOs don't understand business. So at one point we required some of our top project CFOs to serve as project managers in small projects, and some of our big project managers to be project CFOs on small projects. Project CFOs must understand the businesses they serve. On weekends, you can climb towers, or install a base station in a local city suburb. If you don't know how to configure it, you can still screw in the nuts and bolts. That way you'll at least know a little more than others, and you might be promoted faster. Project managers should also learn about finances: For this section of cable, how many man-hours are needed? What is the budget? Go through the calculations. I have approved fast-track promotions for 300 or 400 people in our latest round and some of them are jumping three grades. (Ren Zhengfei: Generals Are Born of Battle-Speech at the 2015 Project Management Summit, Huawei Executive Office Speech No. [2015] 118)

\subsubsection{Integrating Pre-sales and Post-sales Activities}

We must ensure that each large project is managed from end to end. Project estimation, budgeting, accounting, and final accounting span the entire process, from project initiation to payment collection. In reality, this process, which is supposed to be integrated from end to end, has been divided into two segments - sales and delivery. Our incentivization system 
is also fragmented. Incentives are provided in different phases and are not streamlined. This way, we don't know whether a project makes money or not. I think that bonuses for a sales project should be linked to project profitability. The ratio of timely incentive awards for orders needs to be adjusted based on their estimated profitability. This can drive employees to sign high-quality contracts and effectively manage contract terms. For delivery projects, any difference between project budgets and delivery costs is a key factor considered in bonus allocation. Of course, customer satisfaction is the most important factor. We must clearly understand our roles and responsibilities. (Xu Zhijun: Building Capabilities Based on Processes to Realize Sustainable and Profitable Growth and Efficient Operations, SDC Office Doc. No. [2013] 011)

Our management and operations should shift from being functioncentered to being project-centered. Customer projects and product projects will be the primary building blocks of the company's operations. Therefore, improving project operations and management capabilities will be our key means of boosting efficiency and profitability over the next couple of years. In 2015, we will continue to promote project-centered operations and begin piloting the integration of pre-sales and post-sales activities at the project level. We aim to resolve issues in three key areas: delegation of authority to project managers, project resource assurance, and budget management. These initiatives will drive the company to change gradually from a weak matrix structure characterized by "function first, project second" to a strong one characterized by "project first, function second". Through the Strategic Reserve which is made up of elite teams, the Key Project Department, and the Project Management Resource Pool, Huawei aims to expedite the circulation of organizations, talent, technologies, management approaches, and experience during project operations. The purpose of this is to support the company's new operating model, enabling those in field offices to call for support. Under this new model, field teams will have both responsibility and authority while back offices provide enablement training and take responsibility for oversight. (Hu Houkun: Embracing the Future and Building a Better Connected World, Huawei Executive Office Speech No. [2014] 087)

I think project operations are an end-to-end process, involving presales, post-sales, and collection activities. Delivery is only one part of the process. If regional presidents and representative office general managers only pay attention to profitability and ignore contract quality, the pressure of ensuring project profitability will be all passed on to delivery personnel. 
This is unreasonable. (Xu Zhijun: Developing Delivery into Huawei's Core Competencies, Huawei Executive Office Speech No. [2014] 024)

Project owners must manage project operations from end to end, that is, from pre-sales to post-sales. In particular, project owners manage and use project budgets, approve applications for risk contingency, and ensure the attainment of project goals. In pre-sales projects, project directors (PDs) arrange for the signing of high-quality contracts, make estimations, identify major risks and assumptions, and ensure estimation quality. In delivery projects, PDs or project managers (PMs) deliver high quality projects efficiently at low costs based on contracts, ensure the attainment of project goals, and take responsibility for project KPIs such as delivery progress, quality, and customer satisfaction. As core members of project operations, project CFOs and PFCs help project owners and PDs/PMs with project operations. PDs/PMs should ensure process compliance and data accuracy during project operations management. PFCs participate in key operations activities throughout the project lifecycles, give early alerts for any potential risks, and support the attainment of project goals. The key operations activities include project estimation, budgeting, accounting, and final accounting, designing an integrated project financial solution, and developing or changing project plans. Project owners, PDs, PMs, and PFCs are all responsible for project results. (Source: Project Operations and Management Policy, Corp. Doc. No. [2013] 160)

\subsubsection{Closed-Loop Management of Project Risks and Assumptions}

Project estimation is based on a project's delivery solutions, baselines, risks, and assumptions. With quantitative analysis using the total cost model, project estimation can help make more informed sales decisions and optimize solutions, including contract terms, to deliver more competitive solutions. Approved project estimations are the initial goals of a project. Project estimations should include quantitative data, like profits, losses, and cash flow; risks and key business assumptions that have a great impact on estimations; and project sales decision making comments. (Source: Project Operations and Management Policy, Corp. Doc. No. [2013] 160)

The assumptions and risks described in project estimations reflect our expertise. We must make reasonable assumptions and avoid unrealistic risk assessments. When performing project final accounting, we should 
comprehensively assess the actual financial results while reviewing the risks and assumptions described in the estimation phase. If our assumptions and risk assessments deviate too much from actual results, our expertise needs to be improved. (Ren Zhengfei: Speech at a Briefing on the IFS-PFM Project, Huawei Executive Office Speech No. [2013] 074)

From an operations perspective, the IFS program has established a complete set of methodologies for project operations along the LTC process. As key activities of project operations management, our project estimation, budgeting, accounting, and final accounting are respected and implemented throughout the project lifecycle. Many key transformation points have been incorporated into our daily project management. These key points include "project estimation supporting decision making and solution optimization", "on-budget delivery", and "closed-loop management of risks and assumptions". Now, 99\% of project estimations have been archived. Our percentage of budgeted projects has increased from $56 \%$ to $99 \%$. A total of $56 \%$ of projects have identified and quantified potential risks. Through our High Potential Management Elite Team, reserve pools, and PFC Resource Pool, we are transforming from "operating a single project" to "operating batches of high-quality, replicable programs." (Meng Wanzhou: Growing amid Transformation-Thoughts at the Closing of the IFS Program, Improvement Issue No. 463, 2014)

\subsection{Matching Project Managers and Project Management Teams' Authority with Their Responsibilities}

\subsubsection{Matching Project Managers' Authority with Their Responsibilities}

To better serve our customers, we should set up our command centers in places that are closest to customers. We should also give field staff the authority to do planning, budgeting, and accounting and make sales decisions. Back offices will decide whether we should engage in a battle whereas field offices will decide how to fight that battle. Back offices should follow the instructions of field offices, rather than the other way around. HQ should be a support, service, and oversight center rather than a center of centralized governance. (Ren Zhengfei: Speech at the UK Representative Office, Huawei Executive Office Speech No. [2007] 027) 
We should delegate business decision-making authority to field project teams and budgeting authority to project managers. We need to build a project-based incentivization system, and gradually develop a resource buy \& sell mechanism. If representative offices are regarded as companies, they need to pay for all services they require from HQ and regions. We can view representative offices as sales and service companies and projects as independent profit centers. Only a clearly defined resource buy \& sell mechanism can truly reflect project profits and losses. All of these are part of the most basic financial tools that the company is currently promoting: project estimation, budgeting, accounting, and final accounting. With these tools, we will be able to establish more accurate and clear baselines; have a clearer picture of how to continuously increase project profitability; and make our project-based value-sharing and incentivization systems more scientific and reasonable. (Xu Zhijun: Building Capabilities Based on Processes to Realize Sustainable and Profitable Growth and Efficient Operations, SDC Office Doc. No. [2013] 011)

This is going to be a huge change. That means we need to transfer authority from functional departments to project managers. In the future, functional departments will become centers of expertise and resources. Our focus will shift from functional departments to operating teams. Thousands of operating teams, including squads and companies, will be mobilized. (Xu Zhijun: Building Capabilities Based on Processes to Realize Sustainable and Profitable Growth and Efficient Operations, SDC Office Doc. No. [2013] 011)

Why do we delegate more authority to field offices? The reason is quite simple. We aim to give more opportunities to outstanding employees who can work independently and let them leverage their potential based on existing processes and policies. We expect our leaders in field offices to be proactive and creative in our core business and work together toward the same goal. (Ren Zhengfei: Comments to Staff of the Guangzhou Representative Office, Huawei Executive Office Speech No. [2013] 057)

Project owners should be hands-on, manage operations from end to end (from pre-sales to post-sales), and ensure the attainment of project goals. Project owners should be responsive and accountable, and selected from representative offices. (Ren Zhengfei: Speech at a Briefing on the IFSPFM Project, Huawei Executive Office Speech No. [2013] 074)

We will further delegate authority to field offices, so that they can call for support when needed. Project teams are operating units. We are now setting up a large number of subsidiary boards of directors comprised of 
many veteran employees to oversee project implementation. (Ren Zhengfei: Speech at a Meeting with Elite Teams at the Training Camp on July 23, 2013, Huawei Executive Office Speech No. [2013] 174)

We need to transform how we assign responsibility and delegate authority. With effective oversight and proper checks and balances in place, we must fully trust and boldly delegate authority to qualified field commanders based on their job responsibilities, match their authority with their responsibilities, and get closer to our actual business. (Hu Houkun: Correct Values and Strong Management Teams Will Lead Huawei to Long-term Success, Huawei Executive Office Speech No. [2013] 240)

We will continue to drive organizational transformation, streamline management, get closer to our actual business, and give greater autonomy to field offices. The company can grow in size, but our management must not become increasingly complex. Rigorous, well-organized, and simple management is key to scaling new heights. Our efforts will continue to focus on changing HQ from a management and control function to a service and support function. We will give more authority to field offices, to commanders who know best what is going on in the field, so that our organization will be more responsive to opportunities and challenges. In addition, we will integrate all processes at the local and project levels to improve end-to-end efficiency and make it easier for customers to do business with us. (Xu Zhijun: Focusing on Strategy, Streamlining Management, and Achieving Sustainable and Profitable Growth, Huawei Executive Office Speech No. [2013] 246)

We must gradually change our top-down, level-by-level authority delegation model that is centered on functional departments. Instead, we need to give project and program managers the requisite authority to manage project operations based on project goals and budgets. Such authority includes authority related to human resources, finances, and daily operations. In this way, we will increase people's initiative in project and program operations management, and promote sustainable and profitable growth of the company. (Guo Ping: Transform Continuously and Improve Field Operating Capabilities to Ensure the Company's Sustainable and Profitable Growth-Speech at Huawei Annual Management Conference 2013, Huawei Executive Office Speech No. [2014] 020)

The company will gradually implement project-centered operations. All project managers will shoulder responsibilities related to resource usage, personnel appraisal, and financial approval. This is authority mainly relating to human resources, daily operations, and finances. In the past, project 
managers had little authority over human resources, as performance and people management were handled by functional departments. That's why we have added a training session on basics about people and performance management this time. (Ren Zhengfei: Speech at a Meeting with Trainees at the First Training Session for the Global Solutions Elite Team, Huawei Executive Office Speech No. [2014] 064)

The problem we face now is that collective decision making has gone too far. That's why we have placed greater emphasis on individual accountability. We call this the commander ownership system. We need to have control over our committee system. No committees should be set up in field offices. The closer to field offices, the more emphasis we should place on commander ownership; the closer to top management, the more emphasis we should place on collective decision making. Even in a collective decision-making system, committee or team directors should still assume responsibilities. Collective decision making should not be handled in a one-size-fits-all approach, as this will lead to high costs. We need to delegate more authority to lower levels. (Ren Zhengfei: Minutes of a Briefing on the Progress of the Project for Changing Function-centered Operations into Project-centered Operations, EMT Meeting Minutes No. [2014] 019)

\subsubsection{Further Developing Project Management Teams and Inspiring Passion Across Field Operating Units}

Sales decision-making teams (SDTs) are also project steering teams, responsible for winning contracts, ensuring contract-based delivery, and achieving project results. (Ren Zhengfei: Speech at a Briefing on the IFSPFM Project, Huawei Executive Office Speech No. [2013] 074)

With proper checks and balances in place, we will delegate authority to field offices and increase the grades of frontline positions based on their responsibilities and contributions. This can make organizational operations more flexible and cost-effective. (Hu Houkun: Correct Values and Strong Management Teams Will Lead Huawei to Long-term Success, Huawei Executive Office Speech No. [2013] 240)

In terms of operations, we need to adopt a management system where projects are viewed as operating units. How do we define project-centered organizations? What is the role of managers in a project-centered organization? How do we delegate authority and ensure employees are properly incentivized? How do they acquire resources? How can they obtain the 
requisite authority based on budgets? We need to make changes and find answers to these questions. In the future, the management system should be able to cover all projects, be they $\mathrm{R} \& \mathrm{D}$, delivery, transformation, or capital construction projects. A broad management system can cover the entire process from product development, to sales, supply, delivery, and finances. (Ren Zhengfei: Rigorous, Well-ordered, and Simple Management Is Crucial for Huawei to Scale New Heights, Huawei Executive Office Speech No. [2014] 028)

The fundamental reason we adopt a project-centered operating model is that we want to inspire passion across field operating units and improve operating efficiency. (Guo Ping: Becoming Project-centered to Support the Company's Sustainable and Profitable Growth-Speech at the 2014 Project Management Summit, 2014)

\subsection{Project Appraisals and Incentives}

\subsubsection{Adopting an Appraisal and Incentivization Mechanism Based on Final Project Results}

When it comes to authority delegation, value assessment, and incentivization for managers, we should move beyond a department-based mechanism and also establish a project-based mechanism. This will motivate all employees and experts in field offices, $\mathrm{HQ}$, and functional departments to proactively participate in projects. They will work hard to make sure project teams are the most effective and agile operating units in the company that ensure project success. (Ren Zhengfei: Do Not Expand Blindly and Do Not Assume That We Are Already Strong Enough, Huawei Executive Office Speech No. [2012] 006)

We adhere to an appraisal and incentivization mechanism that is based on final project results. All appraisals and incentives must be based on results and responsibilities. Everyone involved in a project must be responsible for the results of their work. Appraisals based on processes rather than results will lead to buck-passing and fragmentation. Phase-by-phase appraisals can be implemented with the support of bonus points. The value of a bonus point must be ultimately determined by project results. (Ren Zhengfei: Speech at a Briefing on the IFS-PFM Project, Huawei Executive Office Speech No. [2013] 074)

Every department has its own unique value and role. Delivery is tasked with building deliverability into contracts; completing deliveries based on 
contract budgets, schedules, and quality requirements; and ensuring high levels of customer satisfaction. This is the primary value Delivery contributes. Delivery project managers may not necessarily participate in enhancing deliverability in front-end activities. Their primary value lies in supporting delivery based on contract budgets, schedules, and quality requirements, and ensuring high levels of customer satisfaction. Based on these considerations, it would be great if they could save some of their budgets. The performance appraisal of project managers at Siemens is very simple. Their budgets are always relatively accurate. Their project managers then can achieve a full appraisal score if they complete delivery according to schedules and quality requirements and come in at 5\% below budget. This rule applies to both delivery and R\&D projects. (Xu Zhijun: Developing Delivery into Huawei's Core Competencies, Huawei Executive Office Speech No. [2014] 024)

Projects are the basic unit of business management. People in the eight critical roles of a project need to assume the most fundamental management responsibilities for project operations. These people must be responsible for achieving project goals and help representative offices achieve their business goals through successful project operations. (Ren Zhengfei: Speech at a Meeting with Trainees at the First Training Session for the Global Solutions Elite Team, Huawei Executive Office Speech No. [2014] 064)

First, we should allow appraisal baselines to vary for different countries and regions. Work in developed regions is a little easier overall, so we should be setting the bar higher there. For example, the baselines for Beijing, Shanghai, and Guangzhou should be higher than those for Xinjiang. Adjusting baselines will encourage dedication in hardship regions and ensure people in these regions are rewarded fairly. (Ren Zhengfei: Minutes of the Briefing on the Progress of Differentiated Appraisals for Regions, Huawei Executive Office Speech No. [2015] 050)

\subsubsection{Exploring Project Bonuses and Implementing the Contribute and Share System}

Project budgets are based on field offices. Profit centers must pay for the services they enjoy, as services come at a cost. If field offices do not choose your services, that means your services are not competitive. In terms of financial resources, human resources, compensation, and bonuses, we need to shift from our current granting system to a Contribute and Share system. Finance needs to explore ways to establish a financial management 
system that runs representative offices as profit centers. (Ren Zhengfei: Speech at a Meeting with Financial Managers, Huawei Executive Office Speech No. [2012] 029)

Regarding incentives based on project results, can we just keep records, rather than require all incentive changes to get approval every time? We should trust in project managers' ability to distribute money fairly. Only by giving them this trust can the authority of project managers match their responsibilities and can they be motivated to effectively manage projects. (Ren Zhengfei: Speech at a Briefing on the IFS-PFM Project, Huawei Executive Office Speech No. [2013] 074)

We need to change our incentivization mechanism and adopt the Contribute and Share system whereby those who contribute more are rewarded more. This system will take root and bloom in a few years. (Ren Zhengfei: Speech at a Meeting with Elite Teams at the Training Camp on July 23, 2013, Huawei Executive Office Speech No. [2013] 174)

In 2012, I suggested that we implement a value-sharing mechanism for delivery projects to continuously reduce our delivery costs. What is a project value-sharing mechanism? For example, suppose the cost budget of a delivery project is US\$1 million based on the capability baseline. However, the project manager motivates project team members to improve delivery efficiency and completes delivery at a cost of only US\$900,000, saving US $\$ 100,000$ for the company. To reward the delivery project team for its contribution, the company will take a portion of the US\$100,000 that was saved to reward the delivery project team. This bonus is recognized as a cost in the books. Capability baselines will also be updated at the same time. In this way, every reward in cost saving will lead to a new delivery capability baseline. By sharing the costs saved, we can fully motivate all delivery employees to continuously improve delivery efficiency and reduce delivery costs. After repeated pushes from Dr. Howard Liang and myself, the value-sharing mechanism has been implemented for managed services projects. However, a consensus on the value-sharing mechanism for delivery projects has not been reached, mainly because the capability baseline for delivery projects has not been set and we cannot ensure accuracy or reliability of project budgets. (Xu Zhijun: Developing Delivery into Huawei's Core Competencies, Huawei Executive Office Speech No. [2014] 024)

We should implement the Contribute and Share system and effectively manage the structure of our value distribution. We need to pay attention to each part of the organization, and allow each and every employee to 
benefit from the company's growth. First, our analysis based on compensation benchmarks must be more reasonable. We need to effectively manage the ratio of how much is distributed to those pulling the cart and how much is distributed to those riding the cart. Pullers should get more than riders, and pullers should get the most when they are pulling the hardest. Second, we must not only widen the gap between the incomes of those at the top of our talent pyramid and top experts in the industry. We must also pay attention to those at the bottom of our pyramid, so we are effectively covering the entire organization. Non-monetary incentives should enable the majority of employees to see opportunities, and inspire them to work hard and strive for excellence. We must not depend solely on monetary incentives to seize strategic opportunities. More importantly, we must develop our strategic and systematic thinking. (Ren Zhengfei: Speech at the Briefing on Recent Motivation Orientations and Principles, Huawei Executive Office Speech No. [2014] 079)

The company has provided guidelines and a framework for project incentives, and regions have proactively implemented project bonuses. We have drawn two conclusions from this for future project incentives. First, project bonuses should come from project profits and should be part of a representative office's annual bonus packages. It has been proposed that bonuses for below-budget execution (also bonuses for project operations improvements) should be included in project costs. As we have not worked out a feasible solution for this, this proposal will not be considered for the time being. Second, the company has two key requirements for delivery projects. One is that delivery must be made on time and on budget, and to a high degree of quality to ensure customer satisfaction. The other is that revenue must increase and costs cut to improve project operations. We have implemented a value-sharing mechanism based on project operations improvements in the managed services projects of GTS and some regions. We encourage field offices to experiment with bonuses for project operations improvements. Regions and representative offices can develop their own solutions, but project bonuses must come from their annual bonus packages. (Source: Minutes of the Work Report on the Project for Changing Function-centered Operations into Project-centered Operations, BOD Executive Committee Meeting Minutes No. [2015] 020)

Project goals must include budget targets - on-budget execution and budget-based improvements. Additional rewards should be given for below-budget execution (i.e., generating more revenue, cutting costs). Project bonuses can be divided into two parts. The first part can be 
awarded for on-budget execution. A project team will receive this part as long as they complete the project on budget. The other part should be used to drive project operations improvements based on budget targets. (Source: Minutes of the Meeting of the Finance Committee Office, July 2015)

Open Access This chapter is licensed under the terms of the Creative Commons Attribution-NonCommercial-NoDerivatives 4.0 International License (http:// creativecommons.org/licenses/by-nc-nd/4.0/), which permits any noncommercial use, sharing, distribution and reproduction in any medium or format, as long as you give appropriate credit to the original author(s) and the source, provide a link to the Creative Commons licence and indicate if you modified the licensed material. You do not have permission under this license to share adapted material derived from this chapter or parts of it.

The images or other third party material in this chapter are included in the chapter's Creative Commons licence, unless indicated otherwise in a credit line to the material. If material is not included in the chapter's Creative Commons licence and your intended use is not permitted by statutory regulation or exceeds the permitted use, you will need to obtain permission directly from the copyright holder. 